\section{A Comparison of CAROC and FRAX in Patients with Fragility Fracture}
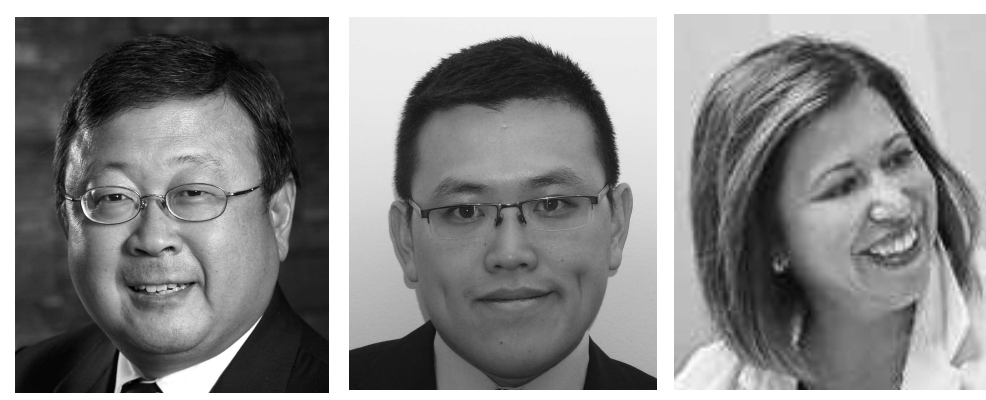

Osteoporosis and the resultant clinically relevant outcome, fractures, are ever increasing in our aging population. Fractures are associated with increased pain, disability, and loss of quality of life, characteristics comparable to those seen in similar chronic diseases such as arthritis and lung disease; not to mention the cost to the patient and society in general $^{1,2}$. Fractures are also associated with frailty, and both frailty and fractures are often predictive of future fractures ${ }^{3}$. Hip and vertebral fractures are associated with increased morbidity and mortality ${ }^{4}$, yet when it comes to those at the highest risk of fracturing ${ }^{5,6}$, we often fail to intervene, and the care gap ${ }^{7}$ that we have seen in the past remains today ${ }^{6}$. It is not uncommon to see patients with multiple fractures continue to fracture without any apparent recognition that these might be caused by osteoporosis ${ }^{6}$ - even in those with hip fractures. Contributing to this may be the lack of self-perceived risk for future fractures by the patient ${ }^{8}$. Further, baseline risk factors, as well as knowledge of osteoporosis and perceived benefits of its treatment, are important predictors of bone mineral density testing and of patient-perceived need for treatment at followup ${ }^{9}$. In addition, the lack of recognition by healthcare workers of this at-risk population, and poor communication between the orthopedic surgeon and the physician responsible for the pharmacologic treatment of the fracture patient ${ }^{10}$, may be part of the cause of the treatment care gap.

As a result, tools have been developed to identify those at risk for fracture ${ }^{11,12}$. Examples include FRAX ${ }^{11}$ (Canadian Fracture Risk Assessment) and CAROC ${ }^{12}$ (Canadian Association of Radiologists and Osteoporosis Canada). Because of the lack of recognition in those at risk for fracture, fracture liaison services have been developed and implemented to improve the care of the fracture patient by improving patient understanding of their fracture risk and by improving the communication between the treating orthopedic surgeon and physician responsible for the evaluation and potential pharmacologic treatment ${ }^{12}$.
It is within this setting that Rotondi, et $a l^{13}$ have compared the use of 2 different fracture risk assessment tools, FRAX ${ }^{11}$ and $\mathrm{CAROC}^{12}$. Both have been validated in the setting of the general Canadian population and were developed to help clinicians determine whether individuals were at moderate to high risk for fracture, and to decide, together with the patient, on future interventions for fracture prevention. It was felt that those at highest risk would benefit most from pharmacologic treatment.

In their report, which appears in this issue of The Journal, Rotondi, et al found that, in general, there was good concordance in older women and greater discordance in men and younger individuals ${ }^{13}$. They point out that this is important when determining fracture risk and deciding on treatment. Despite this discordance, the decision to treat or not treat should not be based solely on a fracture risk tool. Decision making is determined by a complex interaction between patients and their healthcare providers. The decision should be based on this interaction, in which several factors not measured in these tools may be important, and on patient preference. For example, the patient at moderate risk who is otherwise healthy and would prefer not to receive therapy is one who should probably not have therapy; however, the moderate-risk, frail individual with a history of falls might well benefit from treatment. As Moons, et $a l^{14}$ emphasized, "prediction models are not meant to take over the job of the doctor. They are intended to help doctors make decisions by providing more objective estimates of probability as a supplement to other relevant clinical information. Furthermore, they improve understanding of the determinants of the course and outcome of patients with a particular disease."

Finally, Rotondi et al, conducted a sensitivity analysis by combining the low and moderate risk cells to compute a pairwise $\kappa$ estimate across the intervention thresholds, i.e., high risk versus non-high risk (low plus moderate); their analysis showed that the agreement between CAROC and FRAX was high, with a weighted $\kappa(\mathrm{Kw})=0.79(95 \% \mathrm{CI}$ : 0.69-0.89).

See CAROC vs FRAX in fragility fracture, page 1593

Personal non-commercial use only. The Journal of Rheumatology Copyright @ 2016 . All rights reserved. 
They showed that $40.7 \%$ of individuals were identified as being at high risk using FRAX and $46.7 \%$ using CAROC. This is of greatest importance and most helpful in identifying those who would attain the greatest benefit from treatment, one of the goals of these assessment tools. Both tools are reasonably simple and can be incorporated into daily clinical practice, with the promise of offering better care to those at highest risk for fracture.

JONATHAN D. ADACHI, MD, FRCPC

Professor, Department of Medicine,

McMaster University,

Staff Rheumatologist,

St. Joseph's Healthcare Hamilton;

ARTHUR LAU, MD, FRCPC

Assistant Professor, Department of Medicine,

McMaster University,

ALEXANDRA PAPAIOANNOU, MD, FRCPC, Professor, Department of Medicine,

McMaster University,

Hamilton, Ontario, Canada.

Address correspondence to Dr. J.D. Adachi, 501-25 Charlton Ave. E.,

Hamilton, Ontario L8N 1Y2, Canada; E-mail: jd.adachi@sympatico.ca

\section{REFERENCES}

1. Adachi JD, Adami S, Gehlbach S, Anderson Jr FA, Boonen S, Chapurlat RD, et al, for the GLOW Investigators. Impact of prevalent fractures on quality of life: baseline results from the global longitudinal study of osteoporosis in women. Mayo Clin Proceedings 2010;85:806-13

2. Tarride JE, Burke N, Leslie WD, Morin SN, Adachi JD, Papaioannou A, et al. Loss of health related quality of life following low-trauma fractures in the elderly. BMC Geriatr 2016;16:84.

3. Li G, Papaioannou A, Thabane L, Cheng J, Adachi JD. Frailty change and major osteoporotic fracture in the elderly: data from the Global Longitudinal Study of Osteoporosis in Women 3-Year Hamilton Cohort. J Bone Miner Res 2016;31:718-24.

4. Ioannidis G, Papaioannou A, Hopman WM, Akhtar-Danesh N, Anastassiades T, Pickard L, et al. Fractures increase mortality rates: The Canadian Multicentre Osteoporosis Study. CMAJ 2009; 181:265-71
5. van Helden S, Cals J, Kessels F, Brink P, Dinant GJ, Geusens P. Risk of new clinical fractures within 2 years following a fracture. Osteoporos Int 2006; 17:348-54.

6. Langsetmo L, Goltzman D, Kovacs CS, Adachi JD, Hanley DA, Kreiger N, et al. Repeat low-trauma fractures occur frequently among men and women who have osteopenic bone mineral density. J Bone Miner Res 2009;24:1515-22.

7. Fraser LA, Ioannidis G, Adachi JD, Pickard L, Kaiser SM, Prior J, et al. Fragility fractures and the osteoporosis care gap in women: the Canadian Multicentre Osteoporosis Study. Osteoporos Int 2011;22:789-96.

8. Siris ES, Gehlbach S, Adachi JD, Boonen S, Chapurlat RD, Compston JE, et al. Failure to perceive increased risk of fracture in women 55 years and older: the Global Longitudinal Study of Osteoporosis in Women (GLOW). Osteoporos Int 2011;22:27-35.

9. Beaton DE, Dyer S, Jiang D, Sujic R, Slater M, Sale JE, et al. Factors influencing the pharmacological management of osteoporosis after fragility fracture: results from the Ontario Osteoporosis Strategy's fracture clinic screening program. Osteoporos Int 2014;25:289-96.

10. Bogoch ER, Elliot-Gibson V, Beaton DE, Jamal SA, Josse RG, Murray TM. Effective initiation of osteoporosis diagnosis and treatment for patients with a fragility fracture in an orthopaedic environment. J Bone Joint Surg Am 2006;88:25-34.

11. Fraser LA, Ioannidis G, Adachi JD, Pickard L, Kaiser SM, Prior J, et al. Fracture prediction and calibration of a Canadian FRAX® tool: a population-based report from CaMos. Osteoporos Int 2011;22:829-37.

12. Leslie WD, Berger C, Langsetmo L, Lix LM, Adachi JD, Hanley DA, et al. Construction and validation of a simplified fracture risk assessment tool for Canadian women and men: results from the CaMos and Manitoba cohorts. Osteoporos Int 2011;22:1873-83.

13. Rotondi NK, Beaton DE, Elliot-Gibson V, Sujic R, Josse RG, Sale JE, et al. Comparison of CAROC and FRAX in fragility fracture patients: agreement, clinical utility, and implications for clinical practice. J Rheumatol 2016;43:1593-9.

14. Moons KG, Royston P, Vergouwe Y, Grobbee DE, Altman DG. Prognosis and prognostic research: what, why, and how? BMJ 2009;338:b375.

J Rheumatol 2016;43:1456-7; doi:10.3899/jrheum.160712 